\title{
The impact of regional integration on economic growth: empirical evidence from COMESA, EAC and SADC trade blocs
}

\author{
Njoroge Lucas Kamau \\ Central Bank of Kenya, Research Department, \\ P.O. Box 60000-00200 Nairobi, Kenya. \\ Email: njorogelk@centralbank.go.ke, Tel: +254-020-2863252
}

\begin{abstract}
This study examines the impact of economic integration on growth by constructing an economic integration index based on average Most Favoured Nations (MFN) tariffs and the level of regional cooperation for COMESA, EAC and SADC. Applying system GMM estimation technique, the study confirms a positive relationship between economic integration and economic growth. Economic integration and trade, separately and jointly, have a positive and significant impact on growth. The study recommends among other policies, pursuance of nondiscriminatory trade liberalization concomitantly with preferential liberalization in both goods and services, for economic integration to have a significant and sustained positive impact on growth.
\end{abstract}

Keywords: Regional integration, economic growth, SADC trade blocs

\section{INTRODUCTION}

\begin{abstract}
Motivation : Most of the sub-Saharan African (SSA) countries economic performance has been disappointingly low compared to other developing regions. This has been attributed to many factors, among them; is the inability for most African countries to secure access to larger markets, inherent high trade costs among neighbours, lack of an effective framework for regional cooperation and resource pooling, and the pressure from development partners pursuing their own foreign policy objectives in the continent. As a consequence, among other measures geared towards promoting economic growth and development, Africa is witnessing a renewed momentum for integration. Besides, the fear of marginalization together with the fact that, most of the African economies are too small on their own to negotiate with powerful trading blocs, has also led to increased interest towards regional economic integration. The continent has witnessed a shift from "closed regionalism" with import competing approach to a more open approach. What this wave of deepening economic integration efforts implies to economic growth is still under-researched, especially in Africa.
\end{abstract}

Background on Economic Integration in the Three Trade Blocs: The Eastern and Southern Africa trade blocs that are the focus of this study are the Common Market for Eastern and Southern Africa (COMESA), the East African Community (EAC) and the Southern African Development Community (SADC. COMESA, currently with 19 members was established in 1994 as a successor of the Preferential Trade Area (PTA), with the primary objective of achieving regional economic integration and growth. COMESA free trade area was officially launched in October, 2000 and has currently 12 members that are in the process of abolishing internal tariffs and quota restrictions. COMESA has not yet adopted the timetable for the abolition of all non-tariff barriers to intra-community trade. However, the usual non-tariff barriers such as quota restriction, licensing requirements, import permits and foreign exchange controls have been lifted or abated in most countries (Carmignani, 2006). In addition, a number of alternative CETs are presently under consideration.

The Southern African Development Community (SADC), currently with 14 members started as development cooperation in 1980, the Southern African Development Coordination Conference (SADCC), and was reorganized as a development community (SADC) in 1994. SADC approaches regional integration differently by concentrating on relaxing the supply side constraints to trade through regional cooperation in various sectors such as infrastructure, agriculture, transportation and human resources, etc. Although, SADC trade protocol laid less emphasis on timetables for the establishment of 
a customs union or a common market, SADC reached an agreement in 2000 , to create a free trade area. SACU (Southern Africa Customs Union) being a subset of SADC was established in 1910 and recently renegotiated between South Africa, Botswana, Namibia, Lesotho and Swaziland as the new SACU agreement on $21^{\text {st }}$ October 2002. Four of the members fall under a Common Monetary Area, with Botswana withdrawing from its predecessor the Rand Monetary Area in 1974. SACU over the years managed to maintain virtually free internal trade behind a high common external tariff, while allowing for large revenue payments to the smaller members.

The EAC, currently with 5 members, has a long history of cooperation starting with the customs union between Kenya and Uganda that was formed in 1917 and the later entry of the then Tanganyika in 1927. Between 1948 and 1961, these three economies were under the East African High Commission and later between 1961 and 1967 they were under the East African Common Services Organization. This ushered in the 'Old' East African Community in 1967 that served Kenya, Tanzania and Uganda for 10 years until its collapse in 1977. The collapse of the East African Community was provoked by concentration of economic activities in Kenya, which meant unequal distribution of the benefits of integration. The 'current' East African Community followed the signing of the agreement for the establishment of the permanent tripartite Commission for East African Cooperation on November 30 1993. The EAC has had a comprehensive and fast track integration programme, having established a customs union as an entry point to the community common market and subsequently a monetary union and ultimately a political federation (Ndung'u and Goldsten, 2001).

In sum, the three trade blocs of Eastern and Southern Africa forms a good representative sub-set of the trade blocs in Africa since they provide a relatively heterogeneous group of trade blocs. First, SACU which is a subset of SADC presents a fairly advanced forms of regional integration arrangement having achieved a free trade. Within SACU, there is informal free flow of capital and labour enhanced by a common monetary area. Second, the EAC has carried out substantial reductions of internal tariffs with an operational Customs Union since January, 2005. EAC common market protocol that would allow the rights of establishment and free movement of persons is in its final stages of negotiation with the prospects of its signing by the end of 2009. However, EAC can be regarded as a more loose form of economic integration than SACU because it is only in the process of establishing a fully functioning customs union. Thirdly, COMESA, although having established a free trade area is yet to establish a customs union even though it is first tracking its establishment. Hence, COMESA can be regarded as a more loose form of regional integration than EAC. Finally, SADC is yet to introduce tariff reduction or even establish a free trade area and hence can be regarded as one of the loosest form of integration among the three trade blocs. While this clustering is not strictly watertight, it is closely consistent with the United Nations Economic Commission for Africa (UNECA) clustering of regional integration agreements (RIAs) in Africa as fast paced, less fast paced, less slow-paced and slow paced, based on their tariff removal programmes (UNECA, 2004).

The Research Problem: The small size and poor economic base of African countries means that in isolation their development options are narrowly constrained. Their balanced development, and in particular the implementation of any strategy that aims at a significant structural transformation of the economic base demands access to larger than purely national markets and consequently the renewed impetus for economic integration. Whether these efforts towards deeper economic integration have yielded positive results in terms of improved economic performance remains largely unexplored or uncertain.

Since regional integration agreements lead to more liberalized trade among members (and sometimes non members) through increased economic interactions, economic integration should have some implication on growth. In other words, does deeper economic integration significantly influence economic growth in these trade blocs? Alternatively, can deeper economic integration act as an impetus to growth? This is an important issue because growth in the Eastern and Southern Africa region is, by and large, low and highly variable among these countries. The role of economic integration in the growth process has become even more apparent recently, as many developing countries especially in Africa try to determine an appropriate liberalization strategy, for instance, whether they should open their markets to countries from the same region before they open to the rest of the world or just move directly towards non discriminatory liberalization in order to increase their trade flows and accelerate growth? 
Trade Performance in the Three Trade Blocs: The three trade blocs share of world trade over the years has been declining. Figure 1 shows that SADC have a significantly larger share of world trade for the period 1970-2004. Overall, the share of world trade for each of the three trade blocs has been below two percent, indicating that the regional trade blocs have lagged behind and even lost ground with time.

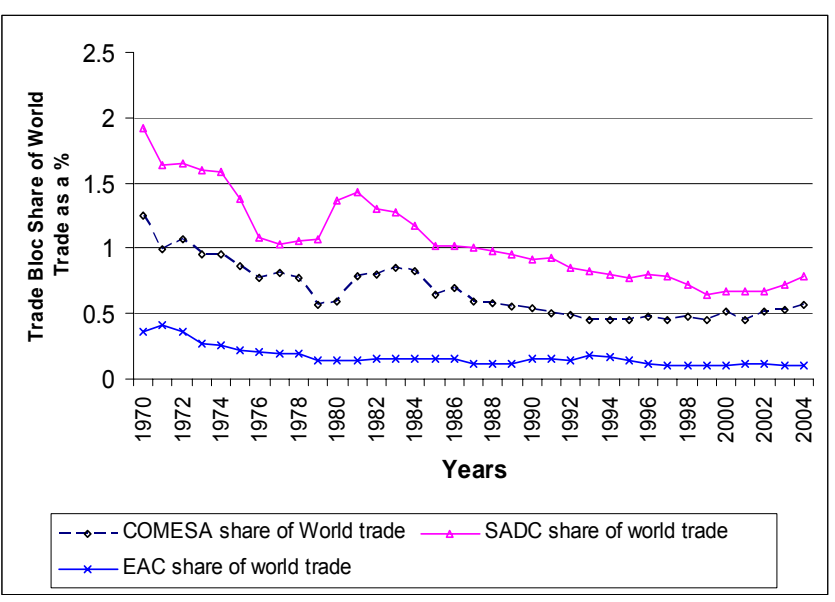

Fig 1 Share of Trade blocs Trade in World Trade, 19702004

Source: Author calculations based on various issues of International Monetary Fund (IMF), Direction of Trade Statistics and WTO-World Trade Report.
This poor trade performance has been attributed to, distorted trade regimes, high transaction costs, inadequate transport, poor information and communication infrastructures, lack of political commitment, policy reversals on trade reforms, multiple and conflicting objectives of overlapping regional arrangements, and limited administrative resources among other factors (Iqbal and Khan, 1997). It has been pointed out that Regional Trade Agreements (RTAs) can play an important role in addressing these hindrances to trade (Oyejide and Elbadawi, 1997). RTAs can help address concerns over policy credibility, function as an agency of restraint, address weaknesses in infrastructure, and harmonize standards and customs procedures among others.

In addition, the intra-regional trade intensity index calculated as the ratio of the intra-regional trade share to a trade bloc's share of world trade also remains low as depicted in Table 1 . This measure has the advantage of adjusting for the size of a trade bloc and its degree of openness to the rest of the world, and hence reflects the tendency for a trade bloc to trade with other partners in the trade bloc.

Table 1: Eastern and southern africa: intra-regional trade intensity index, 1970-2004

\begin{tabular}{lllllllll}
\hline & 1970 & 1975 & 1980 & 1985 & 1990 & 1995 & 2000 & 2004 \\
\hline EAC & 56.7 & 54.2 & 40.5 & 55.7 & 120.6 & 99.4 & 209.1 & 174.0 \\
COMESA & 5.5 & 8.8 & 12.1 & 8.9 & 15.6 & 17.8 & 11.6 & 12.9 \\
SADC & 2.2 & 0.7 & 0.2 & 1.3 & 3.1 & 14.0 & 20.1 & 16.1 \\
\hline
\end{tabular}

Source: Author calculations based on various issues of International Monetary Fund (IMF), Direction of Trade Statistics and WTO-World Trade Reports.

In all cases, the intra-regional intensity indices are greater than 1, confirming that there is a bias towards trading with regional partners. Trade flows between the EAC economies are most highly concentrated. COMESA has relatively constant concentration ratios over time while recently; SADC index shows a remarkable increase. The rapid response of intraregional trade raises important questions as to the possible implication of the 'depth' of economic integration to the overall economic performance of the countries within these trade blocs.
Comparing the 1980s and the years after 2000, the degree of openness has been increasing across all the three trade blocs based on the country level average Most Favoured Nations (MFN) import tariff rates as depicted in Figure 1. The degree of openness vary across the trade blocs and with time, with SADC being relatively more open based on an individual country unilateral liberalization. This suggests that even though EAC and COMESA have made commendable progress in terms of preferential trade liberalization as described by their progress towards deeper regional integration, they lag behind SADC, in unilateral and or multilateral trade liberalization. 


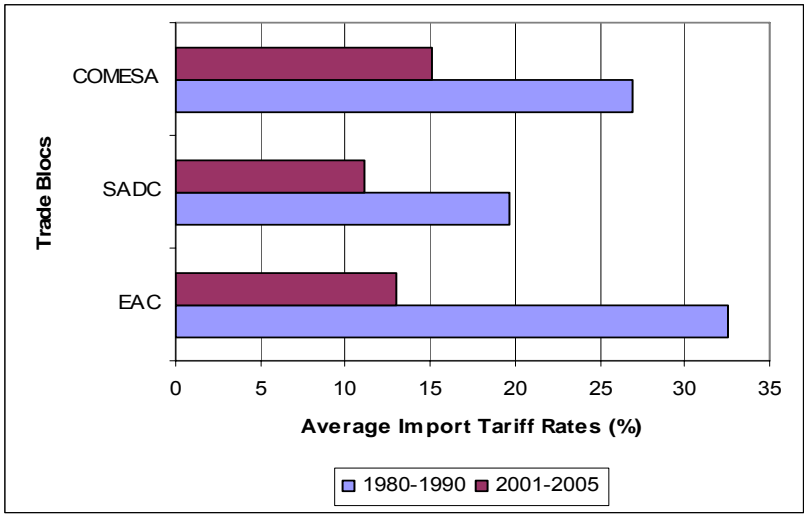

Fig 2 Average MFN Import Tariff Rates

Source: Authors computations from various sources including: The World Integrated Trade Solution (WITS)- WTO Consolidated Tariff data schedule and UNCTAD-Trade Analysis Information System (TRAINS) trade imports and tariff schedules, Trade Policy Review etc.

Theoretical Literature Review: The theoretical analysis of determinants of economic growth is based on both the neoclassical and endogenous growth theories. The neoclassical growth theories, follows the pioneering work by Solow (1956) and predicts that in steady-state equilibrium the level of GDP per capita will be determined by the prevailing technology and the exogenous rates of saving, population growth and technical progress. The theory key assumption is that technical change is exogenous and that the same technological opportunities are available across countries. This implies that the steady state growth solely depends on exogenous population growth and exogenous technical progress. On the other hand, the recent endogenous growth theories instead argue that long run growth is driven by the accumulation of knowledge and thus technology is endogenous, rather than exogenous. By assuming aggregate production functions that exhibit non-decreasing returns to scale, endogenous growth models have provided mechanisms through which economic and social policies can affect long run growth through their effects on human and physical capital accumulation. The main implication of the endogenous growth theories is that human capital is endogenous and hence there need not be diminishing returns to investment.

The theoretical analysis of the impact of regional integration can also be traced to the neoclassical and endogenous growth theories. Under neoclassical growth theory, economic integration, economic policy measures and other institutional aspects have no effect on the steady state growth rate, which is solely determined by the exogenous rate of technological progress. Institutional changes, increases in efficiency or changes in investment ratios following economic integration have only temporary effects on the growth rate. Temporary (Medium term) growth effects occur as a consequence of shifts in the general level of productivity attributed to the formation, deepening or widening of a regional integration agreement. The productivity shift in turn induces accelerated physical capital formation that gradually diminishes towards its long term steady state. Hence, economic integration is seen as any other major economic policy change that affects economic growth only on the transition path leading towards the steady-state.

The endogenous growth models on the other hand, by assuming non-diminishing returns to the accumulation of broadly defined capital predict permanent or long-term effects of economic integration (Walz, 1997). That is, the introduction of human capital and if it keeps up with other investment and knowledge flows freely, returns can be sustained and trade patterns can transfer technology. The access to larger technological base through integration arrangements may in turn speed growth. Economic integration is also seen as expanding the consumer base which may also increase the necessary competition and hence mitigate redundancy in research and development required to generate growth. Economic integration may also lead to intersectoral and international reallocation effects or trigger economic geography forces (Krugman, 1991). For this study, what is of essence is the fact that the impact of economic integration on growth can be traced back to the production function and hence compatible with the necessary extensions of the neoclassical and endogenous growth theories.

Empirical Literature Review: The empirical studies reveal that many factors have been identified as determinants of growth, with various factors attributed for Africa's dismal economic performance. They include poor domestic policies, relatively small sizes of individual economies, geography, colonial legacy, political instability, weak institutions, lack of openness, and inhospitable external environment among other factors. Besides, economic factors such as initial conditions, investments, population growth, 
human capital development, government consumption, openness, financial development and the political environment among other factors, have been found to determine economic growth in Africa (Collier and O'Connell, 2004; Burnside and Dollar, 2000; Bates, (2005); Bloom and Sachs, 1998 among others).

However, most of the literature on growth does not examine the impact of regional economic integration on growth, while the few that have been done on the subject reveal an inconclusive debate. Findings range from a positive or a negative impact to a no or ambiguous effects. Vamvakidis (1999) show that participating in regional integration agreements (RIAs) was on average associated with slower growth rates than following a policy of broad liberalization. $\mathrm{He}$ attributes this to the fact that regional integration arrangements are often implemented at the expense of broad liberalization. Torstensson (1999), identified investment and knowledge transfers as the channels linking economic integration to growth for OECD countries. Landau (1995) finds that there was no long-term growth effects associated with membership to the European Commission (EC). Badinger (2001) finds no permanent increase in growth rates related to economic integration within the European Union. Spilimbergo et al. (1999) theoretically shows that RIAs could inhibit growth by changing the composition of trade in favour of low-technology goods or goods with less learning-by-doing. Vanhoudt (1999) using a panel of 23 OECD countries finds no positive or negative growth effects for the EC members in comparison to non-member OECD states. Hence, the impact of RIAs on economic growth remains an empirical question.

Another strand of literature is concerned with NorthSouth regional integration agreements. Most of these studies find unilateral liberalization beneficial but argue that the gains from integration are likely to be larger, bringing greater benefits to developing countries in the case of North-South relative to South-South regional integration agreements (Puga and Venables, 1998; Venables, 2003). Gunning (2001), Lyakurwa (1996) and Aryeetey and Oduro (1996) corroborate the positive contribution of economic integration on growth in Africa, attributed to trade reforms, increased investments and trade. Venables (2003) gives evidences that the SouthSouth integration does not matter and describes North-South as just good while North-North as better.

\section{METHODOLOGY}

The Empirical Model: The empirical model is derived from the neoclassical augmented Solow model, based on a Cobb-Douglas production function with labour-augmenting technological progress, extended to a panel data formulation to:

(1)

$$
\begin{aligned}
& \operatorname{Iny}\left(t_{T}\right)=\left(1-e^{-\phi T}\right) \frac{\alpha}{1-\alpha-\beta} \operatorname{Ir}\left(s_{k}\right)+\left(1-e^{-\phi T}\right) \frac{\beta}{1-\alpha-\beta} \operatorname{In}\left(s_{h}\right)-\left(1-e^{-\phi T}\right) \frac{\alpha+\beta}{1-\alpha-\beta} \operatorname{In}(n+g+\delta) \\
& +e^{-\phi T} \operatorname{Iny}\left(t_{0}\right)+\left(1-e^{-\alpha T}\right) \operatorname{In}(0)+g\left(t_{T}-e^{-\phi T} t_{0}\right)
\end{aligned}
$$

where the equation imply that, growth in GDP per capita, $\bar{y}\left(t_{T}\right)$ depends on initial output per capita, $y\left(t_{0}\right)$; the initial level of technology, $A(0)$; the rate of technological progress, $g$; the proportion of output invested in physical and human capital, $S_{k}$ and $S_{h}$ respectively; the growth rate of the workforce, $n$; the depreciation rate, $\delta$; and the share of physical and human capital in output $\alpha$ and $\beta$. Equation (1) represents the final model for estimation which is a dynamic panel data formulation with $\left(1-e^{-\phi T}\right) \operatorname{In} A(0)$, as the time-invariant individual country-effect term. Equation (1) can be expressed in conventional notation of dynamic panel data specification as:

$$
y_{i t}=\Pi y_{i, t-1}+\sum_{j=1}^{3} \lambda_{j} x_{i t}^{j}+\eta_{t}+\mu_{i}+v_{i t},
$$

where, $\quad y_{i t}=\ln y\left(t_{T}\right), \mathrm{y}_{\mathrm{i}, \mathrm{t}-1}=\ln \mathrm{y}\left(\mathrm{t}_{0}\right), \Pi=\mathrm{e}^{-\Phi \mathrm{T}}, \lambda_{1}=$ $\left(1-e^{-\Phi T}\right)(\alpha / 1-\alpha-\beta), \lambda_{2}=\left(1-e^{-\Phi T}\right)(\beta / 1-\alpha-\beta), \quad \lambda_{3}=-\left(1-e^{-}\right.$ $\left.{ }^{\Phi T}\right)(\alpha+\beta) /(1-\alpha-\beta), x^{1}{ }_{i t}=\ln \left(s_{k}\right), x^{2}{ }_{i t}=\ln \left(s_{h}\right), x^{3}{ }_{i t}=\ln$ $(\mathrm{n}+\mathrm{g}+\bar{\delta})$,

$\mu_{\mathrm{i}}=\left(1-\mathrm{e}^{-\Phi T}\right) \ln \mathrm{A}(0), \eta_{\mathrm{t}}=\mathrm{g}\left(\mathrm{t}_{\mathrm{T}}-\mathrm{e}^{-\Phi T} \mathrm{t}_{0}\right)$, and $u_{i t}=\mathrm{a}$ transitory error term that varies across countries and time periods and has mean equal to zero. In equation (2), t denotes points in time such that, $y_{i t}$ reflects the average growth rate of per capita GDP over a series of five year periods, with $y_{\text {it-1 }}$ being the level of income per capita at the beginning of each of these periods and $x_{i t}$ being measured either at the beginning of each period, or as an average over each period. This equation is based on approximation around the steady state and helps capture the dynamics towards the steady state. The term $g+\delta$ is assumed to be the same for all countries (Barro, 1991; Levine and Renelt, 1991 and 1992). 
Following Barro and Sala-i-Martin (1995), the relevant conditioning variables for the countries of Eastern and Southern Africa are included. This gives the following model for estimation:

$$
\text { (3) } y_{i t}=\sum \lambda_{X i} x_{i t}+\beta_{Z i} z_{i t}+\alpha_{E i} E_{i t}+\eta_{t}+\mu_{i}+v_{i t} \text {, }
$$

where $x$ is a vector of important explanatory variables referred to as 'free variables' (basic augmented neoclassical growth variables) that always appear in the regressions, $E$ denotes the variable of interest, the economic integration index (EII) and or Intra regional trade intensity index, ITCR. $z$ is a vector of additional predetermined conditioning variables from previous studies for African countries.

The set of conditioning variables relevant to subSaharan Africa tend to be crucially different and a separate treatment of these countries warrant investigation. Therefore, this study uses the following variables that have dominated Africa growth literature. Government consumption ratio to GDP as a measure of fiscal policy; Intra regional trade intensity index captures the openness of the economy based on the ratio of the intra-regional trade share to each region's share of world trade; Political Instability Index as a measure of institutional weakness; Landlocked variable captures the importance of geographical proximity among trade bloc members; the Age dependency ratio captures effect of demographic variables on the growth rate of real GDP per capita; gross fixed capital formation as a share of GDP captures the role of investments in the growth process; lag of GDP per capita capturing convergence/divergence among trade bloc members, Gross secondary school enrolment capturing the role of education and the Economic Integration Index.

The Economic Integration Index: Most countries in the three trade blocs pursued interventionist and protectionist trade regimes for a long time that were aimed at promoting industrialization and raising government revenue. However, since 1980s, trade reforms in the region have been implemented under three platforms. First, countries that sought the assistance under the IMF/World Bank structural adjustment programmes were compelled to embark on unilateral trade liberalization. Second, through regional integration arrangements countries agree on the extent of trade liberalization among them and against the rest of the world. Finally, African countries have also taken part in multilateral trade reforms as a result of their membership to the World Trade
Organization (WTO). Through these trade reforms, economic interactions and exchanges have risen between countries within trade blocs and with the rest of the world, promoting economic growth and development.

Although most trade reforms in Africa were initiated in the second half of the 1980s, substantial progress was not observed in the region until the 1990s. This is illustrated by the fact that in the early 1980s, the average tariffs in most African countries was about 25 percent, while by the year 2000; it had declined to roughly 18 percent. More specifically to the three trade blocs, the average tariffs in the early 1980s were above 20 percent, 25 percent and 30 percent compared to the rates in the period 2001-2005 of 11 percent, 15 percent and 13 percent for SADC, COMESA and the EAC respectively.

Given these developments, an economic integration measure should take into account the degree of trade restrictiveness within and between the integrating economies. However, there is no consensus in the literature on how to measure economic integration or the degree of trade restrictiveness. On measuring economic integration, a number studies use dummy variables for membership in a trade bloc (i.e. Vanhoudt, 1999), or proxies for the market expansion in terms of population, GDP or area (.i.e. Landau, 1995) or the share of intra bloc trade in total trade (.i.e. Badinger, 2001).

This study develops an economic integration index that captures two main aspects that facilitate economic integration. First, it considers trade reforms within a particular trade bloc capturing the various efforts of individual member countries towards freer trade. Second, trade reforms by a particular trade bloc and with the rest of the world, capturing efforts at a trade bloc level to freer trade are considered. The index takes up these two issues and provides various alternative policy combinations for member countries of the three trade blocs. A ten point classification scheme is constructed that combines measures of import tariffs reduction and the pace towards deeper regional integration for the three trade blocs of Eastern and Southern Africa.

For measures of import tariffs, the study classifies average import tariff rates as either low or high where low average import tariff is when the MFN/custom duty rate is less than 25 percent and high if equal or greater than 25 percent, for a given country in a 
particular trade bloc. The choice of this threshold rate reflects the general Africa's average MFN tariff rates in the 1980s, the mid decade between the earlier period of high average tariff rates regime of the 1960s and 1970s, and the later period of trade liberalization and reduced tariffs regime of the late 1980 s to the current period. The study could not include other measures of trade restrictiveness such as non tariff barriers (NTBs) because for almost all the countries in this study, data on NTBs is either completely lacking or where some data is available; it tends to be too general for one to make any specific inference on the progress made in reducing such barriers.

On the measures of the pace towards deeper regional integration, the study came up with 5 broad categories, namely; CET: represents common external tariff (CET) and includes countries in a trade blocs that have a functioning customs union. PCET: represents -in the process of establishing a common external tariff and includes countries in a trade bloc that have implemented a customs union protocol and are in the process of establishing or have recently established a common external tariff. FTA: represents a free trade area and includes countries in a trade bloc that have a functioning free trade area. PFTA: represents -in the process of establishing a free trade area and includes countries in a trade bloc that is in the process of establishing a free trade area. NoFTA: represent no free trade area and includes countries in a trade bloc that have not formally established FTAs but cooperate in a number of trade and development aspects. A ten point classification scheme is constructed that combines measures of average import tariffs and the degree of regional integration as represented in a matrix form in Table 2

Table 2 indicates that, the higher the rank, the least restrictive a country is and the deeper its degree of economic integration. On one extreme, when a country belongs to a functioning customs union and has lower average import tariffs, it is assigned the highest rank. This is because for most regional integration arrangements, deep economic integration in Africa so far involves lower internal MFN import tariff rate and belonging to a functioning customs union. Therefore, belonging a CET is regarded to be least restrictive to trade within a trade bloc, while lower MFN import tariff rate (a rate of less than 25 percent) is regarded as least restrictive to trade with the rest of the world.

Table 2 interaction between the pace of economic integration and average $\mathrm{mfn}$ tariff

\section{RATES}

\begin{tabular}{|l|l|l|}
\hline Rank & $\begin{array}{l}\text { Pace towards deeper } \\
\text { Regional Economic } \\
\text { Integration }\end{array}$ & $\begin{array}{l}\text { Average Import } \\
\text { Tariff rate }\end{array}$ \\
\hline 10 & CET & low \\
\hline 9 & CET & high \\
\hline 8 & PCET & low \\
\hline 7 & PCET & high \\
\hline 6 & FTA & low \\
\hline 5 & FTA & high \\
\hline 4 & PFTA & low \\
\hline 3 & PFTA & high \\
\hline 2 & NoFTA & low \\
\hline 1 & NoFTA & high \\
\hline
\end{tabular}

Source: Authors calculations based on tariffs data from WITS, WTO Consolidated Tariff data schedule and, UNCTAD-Trade Analysis Information System (TRAINS). Low stands for less than 25 percent, and High stands for equal to or greater than 25 percent.

On the other extreme, NoFTA/high represents a trade regime with a high import tariff rate for a country that is a member of a trade bloc that has not made much progress towards becoming a FTA, if any. This category is assigned the lowest rank representing the worst case scenario. This is because a member of a trade bloc that has not made much progress towards becoming a free trade area and has high import tariffs ( tariff rate greater than or equal to 25 percent), tends to shield itself from the rest of the world. This means that trade is not only restricted within the trade bloc but also with the rest of the world, depicting shallow economic integration. Based on Table 2 economic integration indices for all the countries in the three trade blocs are provided in Table 3 . The general guide to constructing the indices in Table 3 is grouping the countries in the three trade blocs as follows: CET includes only SACU members, PCET includes the EAC members, FTA includes COMESA members except the late comers who fall under PFTA, NoFTA includes the rest of the SADC member countries. For those countries with overlapping membership, priority when assigning the index is given to the more advanced regional integration category of the overlap. 
Table 3: the economic integration index

\begin{tabular}{|c|c|c|c|c|}
\hline \multirow[b]{2}{*}{ Country } & \multicolumn{4}{|c|}{ Period } \\
\hline & Before 1980 & $1981-1990$ & $1991-2000$ & 2001-2005 \\
\hline Angola & 5 & 6 & 6 & 6 \\
\hline Botswana & 9 & 10 & 10 & 10 \\
\hline Burundi & 3 & 3 & 4 & 4 \\
\hline Comoros & 3 & 4 & 4 & 4 \\
\hline DRC & 5 & 6 & 6 & 6 \\
\hline Djibouti & 5 & 5 & 5 & 6 \\
\hline Eritrea & 5 & 5 & 5 & 6 \\
\hline Egypt. Arab Rep. & 5 & 5 & 5 & 6 \\
\hline Ethiopia & 5 & 5 & 5 & 6 \\
\hline Kenya & 7 & 7 & 7 & 8 \\
\hline Lesotho & 9 & 10 & 10 & 10 \\
\hline Libya & 3 & 3 & 4 & 4 \\
\hline Madagascar & 5 & 6 & 6 & 6 \\
\hline Malawi & 5 & 6 & 6 & 6 \\
\hline Mauritius & 5 & 6 & 6 & 6 \\
\hline Mozambique & 1 & 2 & 2 & 2 \\
\hline Namibia & 9 & 10 & 10 & 10 \\
\hline Rwanda & 3 & 3 & 3 & 4 \\
\hline Seychelles & 5 & 5 & 5 & 6 \\
\hline South Africa & 9 & 10 & 10 & 10 \\
\hline Sudan & 5 & 5 & 6 & 6 \\
\hline Swaziland & 9 & 10 & 10 & 10 \\
\hline Tanzania & 7 & 7 & 8 & 8 \\
\hline Uganda & 7 & 7 & 8 & 8 \\
\hline Zambia & 5 & 6 & 6 & 6 \\
\hline Zimbabwe & 5 & 6 & 6 & 6 \\
\hline
\end{tabular}

Source: Author computation.

For example, since Tanzania is a member of both SADC and the EAC, it is categorized as only a member of the EAC because EAC is regarded as a PCET (seen as a more advanced level of economic integration) and not as SADC which is regarded as a NoFTA category (less advanced level of economic integration). From Table 3, this information is utilized to construct a dummy variable that is used for estimation in the empirical models. The dummy variable takes the value of 1 if the economic integration index in a given year is equal to or above index 5, and hence depicts deep economic integration while it takes a value of zero if the economic integration variable is less than index 5 in Table 3 . The demarcation index 5 was dictated by the fact that most of the regional integration schemes in
Africa are still evolving and very few have even really taken off and therefore a free trade area level seems reasonable if one is interested in the degree of economic integration in this region.

Estimation Issues, scope of the study and data sources: Recent adoption of panel-data estimation techniques combines the dynamics in time series with cross sectional variation in the analyses of the determinants of economic growth in an attempt to solve most of the econometric challenges of cross sectional data estimation. Combining cross-section and time series data is useful for three main reasons. First, it is necessary when analyzing growth especially in Africa, because the growth performance of developing countries varies substantially over time, and the time-series dimension of the variables of 
interest provides a wealth of information ignored in cross-sectional studies. Secondly, the use of panel data allows expanding the sample size, and the gain in the degrees of freedom is particularly important when a relatively large number of regressors are used. Thirdly, panel data estimation can improve upon the issues that cross-sectional data fail to address, such as potential endogeneity of the regressors, and controlling for country specific effects. Following recent advances in panel data estimation methods, this study therefore utilizes system GMM (generalized method of moments) technique which addresses the problems of omitted variable bias, endogeneity, and unit root effects in the choice of instruments. Whilst there are a number of maximum likelihood and bias-corrected Within Groups estimators that have been proposed for dynamic panel data models, it is far from clear how these others are affected by the presence of measurement error and endogenous variables.

This study covers the period 1970 to 2008 . The three trade blocs of Eastern and Southern Africa cut across most of SSA countries whose poor economic performance has attracted a lot of interest in the growth literature. Besides, using the three trade blocs provides a richer data set than would be a single trade bloc in the sense that the sample of countries is relatively heterogeneous besides increasing the degrees of freedom necessary for consistent and efficient system GMM estimation. Using the three trade blocs also helps capture uniquely the role of economic integration in the growth process. The main sources of the data for this study are the World Bank and International Monetary Fund (IMF) sources.

\section{EMPIRICAL RESULTS}

Two sets of results are presented, one, for models with only one of the variables of interest (i.e. either the economic integration index, Ell or the Intra Trade concentration ratio, ITCR) and two, models for the joint effects of the two variables. This distinction allows clear understanding of the effects of these variables separately and jointly. The need to isolate the effect of the economic integration index and the trade variable comes from the fact that, the economic integration variable by construction captures openness not only at an individual country level but also for integrating economies and therefore acts as a pointer for enhanced trade among integrating economies. This means that although the economic integration index is completely independent by construction from the ITCR variable, its impact on economic growth should be consistent with the impact of ITCR on growth, that is, trade should lead to an increase in the growth rate of GDP per capita, if economic integration index influences growth positively.

One step estimates of the system GMM estimator are reported. Blundell and Bond (1998) showed that for finite samples, the asymptotic standard errors associated with the two step system GMM estimators can be seriously biased downwards, while Monte Carlo simulations have shown that inference based on the one-step estimator is more reliable especially when the levels error term is heteroskedastic as is the case in panel data sets. The study assumes that continuous variables affect growth nonlinearly, and hence enters all the variables as logarithms, except for dummy variables and indices

For all the results, asymptotic standard errors, asymptotically robust to heteroscedasticity are reported in brackets. The AR (1) and AR (2) tests of first and second-order serial correlation in the first differenced residuals report their $p$-values statistics. The $p$-values give the probability of correctly rejecting the null hypothesis of no autocorrelation. It is required that the AR (1) test of first-order autocorrelation rejects the null while the test for second-order autocorrelation fails to reject the null hypothesis of no autocorrelation (Arellano and Bond, 1991; 1998). Therefore, system GMM estimator is consistent only when second-order correlation is not significant although first-order correlation need not be zero. With respect to the Sargan test of over-identifying restrictions, the p-values should fail to reject the null hypothesis that the set of instruments is appropriate. That is, the Sargan test should be insignificant for the set of instruments to be validity (Arellano and Bond 1991, 1998). Wald dummy test is reported since all the regressions include period time dummies. All these diagnostic tests for the appropriateness of the instruments are provided in the second part of each table. The results in table 4 indicate that all the diagnostic tests support the validity of the system GMM estimator. Joint inclusion of the two variables of interest (ITCR and EII) gives the results in equation 3. 
Am. J. Soc. Mgmt. Sci., 2010, 1(2): 150-163

Table 4: SYS-GMM DPD Regression Results

\begin{tabular}{|c|c|c|c|}
\hline Variables & $\mathrm{EQ}(1)$ & $\mathrm{EQ}(2)$ & $E Q(3)$ \\
\hline \multicolumn{4}{|l|}{ Fixed Variables } \\
\hline $\ln \left(G^{\prime} P_{t-1}\right)$ & $\begin{array}{l}0.121016 \\
(0.05358)^{* *}\end{array}$ & $\begin{array}{l}0.0942593 \\
(0.04535)^{\star *}\end{array}$ & $\begin{array}{l}0.164571 \\
(0.09116)^{\star *}\end{array}$ \\
\hline In (Investment) & $\begin{array}{l}0.0496239 \\
(0.02000)^{* *}\end{array}$ & $\begin{array}{l}0.0532689 \\
(0.02236)^{\star *}\end{array}$ & $\begin{array}{l}0.0582160 \\
(0.02989)^{\star *}\end{array}$ \\
\hline $\ln (n+g+d)$ & $\begin{array}{l}-0.0199686 \\
(0.01251)\end{array}$ & $\begin{array}{l}-0.00547437 \\
(0.01986)\end{array}$ & $\begin{array}{l}-0.00717904 \\
(0.02202)\end{array}$ \\
\hline In (GERSEC) & $\begin{array}{c}0.00697986 \\
(0.008679)\end{array}$ & $\begin{array}{l}0.008411 \\
(0.01031)\end{array}$ & $\begin{array}{l}0.00283487 \\
(0.02563)\end{array}$ \\
\hline \multicolumn{4}{|l|}{ Variable of Interest } \\
\hline$\overline{E I I}$ & $\begin{array}{l}0.356201 \\
(0.1188)^{\star * *}\end{array}$ & & $\begin{array}{l}0.0168299 \\
(0.009589)^{* *}\end{array}$ \\
\hline ITCR & & $\begin{array}{l}0.324250 \\
(0.1055)^{\star \star *}\end{array}$ & $\begin{array}{l}0.111036 \\
(0.04963)^{\star *}\end{array}$ \\
\hline \multicolumn{4}{|l|}{ Institutional Variables } \\
\hline $\mathrm{PII}$ & $\begin{array}{l}-0.0400690 \\
(0.01835)^{\star *}\end{array}$ & $\begin{array}{l}-0.0214451 \\
(0.007752)^{\star * *}\end{array}$ & $\begin{array}{l}-0.0980952 \\
(0.03641)^{* *}\end{array}$ \\
\hline \multicolumn{4}{|l|}{ Other Variables } \\
\hline $\ln$ (Govcon) & $\begin{array}{l}-0.0349308 \\
(0.01528)^{* *}\end{array}$ & $\begin{array}{l}-0.0782663 \\
(0.03307)^{\star *}\end{array}$ & $\begin{array}{l}-0.0266231 \\
(0.01027)^{\star *}\end{array}$ \\
\hline Landlocked & $\begin{array}{c}-0.0217584 \\
(0.01196)^{\star *}\end{array}$ & $\begin{array}{l}-0.0565724 \\
(0.03119)^{\star \star}\end{array}$ & $\begin{array}{l}-0.0132752 \\
(0.02647)\end{array}$ \\
\hline Constant & $\begin{array}{l}-0.0329882 \\
(0.02308)\end{array}$ & $\begin{array}{l}-0.000208531 \\
(0.0002039)\end{array}$ & $\begin{array}{l}-0.00825148 \\
(0.08564)\end{array}$ \\
\hline \multicolumn{4}{|l|}{ Model Tests } \\
\hline Wald (Joint) & $\begin{array}{l}48.87 \\
(0.000)^{\star * *}\end{array}$ & $\begin{array}{l}25.16 \\
(0.001)^{\star * *}\end{array}$ & $\begin{array}{l}48.33 \\
(0.000)^{\star * *}\end{array}$ \\
\hline Wald (dummy) & $\begin{array}{l}8.755 \\
(0.003)^{\star \star \star}\end{array}$ & $\begin{array}{l}5.771 \\
(0.016)^{\star *}\end{array}$ & $\begin{array}{l}12.12 \\
(0.000)^{\star * *}\end{array}$ \\
\hline Sargan Test & $\begin{array}{l}28.18 \\
(0.209)\end{array}$ & $\begin{array}{l}21.60 \\
(0.545)\end{array}$ & $\begin{array}{l}23.40 \\
(0.379)\end{array}$ \\
\hline AR(1) Test & $\begin{array}{l}-2.593 \\
(0.010)^{* * *}\end{array}$ & $\begin{array}{l}-2.632 \\
(0.008)^{\star * *}\end{array}$ & $\begin{array}{l}-2.228 \\
(0.026)^{\star *}\end{array}$ \\
\hline AR(2) Test & $\begin{array}{l}1.287 \\
(0.198)\end{array}$ & $\begin{array}{l}1.347 \\
(0.178)\end{array}$ & $\begin{array}{l}1.341 \\
(0.180)\end{array}$ \\
\hline
\end{tabular}

*** imply significant at 1 percent, ${ }^{* *}$ imply significant at 5 percent, and * significant at 10 percent

The results indicate that all the regressors are significant at 5 percent level except the constant, adjusted population growth rate $(\ln n+g+d)$ and gross secondary school enrolment rate (In GERSEC) in all the three models. These results are consistent with theoretical prediction and broadly in line with the findings of the relevant empirical literature (for instance, Pritchett, 1996). In line with augmented Solow model, the log of GDP per capita lagged one period $\left(\operatorname{InGDP}_{\mathrm{t}-1}\right)$ which is a proxy for the initial conditions, is statistically significant and positive and hence fails to support conditional convergence for the countries of EAC, SADC and COMESA. This suggests that, given the small initial income, countries of Eastern and Southern Africa trade blocs should tend to grow faster especially after conflicts as was demonstrated by the experiences of Uganda and Rwanda. The results are consistent to similar studies in the literature. Jenkins et al. (2000) tried to assess whether convergence might occur and finds that within SADC as a whole, economies diverged between the periods 1960-1990.

Since most of these countries are among the poorest in the world with the majority of their people surviving on less than a dollar a day, funds for investment may not abound because a large part of income is used to satisfy basic needs. Resources are devoted to subsistence consumption rather than to savings. Countries consuming at the subsistence level exhibit divergence from other countries and, in most cases, also from one another - a state of affairs that can last for a considerable period of time and appears to be 
quite consistent with the empirical evidence (BenDavid, 1996).

The ratio of investment to GDP (In Investment) as expected is positive and significant at 5 percent in all the three equations, indicating that investment is a strong determinant of per capita growth for these countries and an important policy variable. This may imply that its low levels in these countries could have led to low real GDP per capital growth rate over time.

On the variable of interest to this study, economic integration index has a positive and statistically significant impact on growth for the countries of Eastern and Southern Africa. This implies that regional integration when accompanied with WTO compatible trade reforms, increases economic interaction between countries and ultimately improves there economic performance. That is, implementing more open trade policies and integrating faster with each other and with the rest of the world may mean more growth on average in these countries.

The results of the Political Instability Index (PII) broadly remain similar in all the three regressions in Table 4. The variable has a negative statistically significant impact on the growth rate of real GDP per capita. This shows how large devastating effect of political instability may be on economic growth. This implies that, to be involved in any form of political instability will definitely translates into a slowdown of the home and neighbours economy.

Government consumption to GDP ratio is also statistically significant and has the expected negative sign in all the three regressions. This suggests that, for most of these countries, a large proportion of government expenditure is on unproductive activities. This may not be surprising given that most of these countries have gone through many episodes of mismanagement and rampant corruption. The landlocked dummy has the expected negative and significant impact on growth in equations 1 and 2 . This suggests the importance of transport costs in inhibiting growth, for the countries of Eastern and Southern Africa trade blocs that have limited, if any roads or railways intra or interconnectivity.

The intra-regional concentration ratio (ITCR) is positive and significantly impacts on the growth rate of real GDP per capita. This means that trade is concentrated in the region more than the size and the openness of the trading partners would suggest. That is, most of these countries trade more with their partners in a trade bloc because they are also neighbouring countries or they share a common language rather than because of preferences. This could also mean that geographical proximity matters confirming the results that transport costs greatly hamper intra-regional trade for these countries given the undeveloped state of regional infrastructures.

However, the results in equation 3 are slightly different since the joint inclusion of ITCR and the EII makes the coefficient of landlocked dummy insignificant. This could mean the effect of landlocked dummy depends on whether an economy is relatively open within a trade bloc and with the rest of the world. That is, if countries pursue aggressively trade reform measures at a trade bloc level and also opens up to the rest of the world, the negative impact of being landlocked is greatly reduced or even become insignificant, as is the case in these models.

CONCLUSION AND POLICY IMPLICATIONS: Overall, the study results are congruent to the theoretical and empirical literature on growth determinants especially in Africa. The positive impact of the initial GDP on growth used as a proxy for initial conditions suggests that economies within the trade blocs of Eastern and Southern Africa have experienced income divergence in the period 19702004. The role of savings on growth is captured by the positive effect of investment to GDP ratio, the negative effect of the political instability index underscores the impact of political instability while the negative effect of government consumption captures the adverse effect of fiscal indiscipline associated with most African countries. Landlocked negative effect on the growth rate of per capita GDP provide evidence of the high transaction and transport costs on trade flows within and among the trade blocs of Eastern and Southern Africa that ultimately inhibit economic growth. However, this negative effect of being landlocked becomes insignificant when both economic integration index and openness indicator are jointly included as growth determinants, suggesting that pursuing trade reforms simultaneously at a country level and at a trade bloc level greatly diminish the negative effect of being landlocked.

Specific to the variables of interest for this study, a robust positive relationship between intra regional trade intensity index and economic integration index 
separately and jointly on growth is found. This suggests that the greater the pace towards deeper regional integration between members of a trade bloc leads to higher economic performance. In addition, less restrictive trade policies within each country and as a trade bloc with the rest of the world also promotes economic growth for countries of Eastern and Southern Africa. This point to the important role played by deep economic integration involving regional integration and WTO compatible tariffs reduction on growth. Unilateral, multilateral and preferential trade reforms when pursued simultaneously have a significant impact on growth.

This study therefore recommends pursuance of nondiscriminatory liberalization concomitantly with preferential liberalization, in both goods and services as a strategy for enhancing economic performance among the countries of Eastern and Southern Africa. The results support the conclusion that regional trade cooperation can support the expansion of trade and in turn boost economic growth for the countries of Eastern and Southern Africa. The study notes that intra-regional trade within these trade blocs is beset by a host of obstacles ranging from distortions in the trade regimes to inadequacies in the customs, transport and communications infrastructure

Although the three trade blocs have made considerable progress in integrating their economies, there is room for improvement that would help member countries reap even high benefits from economic integration. First, there is need to address the issue of lack of political will among integrating economies. Lack of political will as demonstrated by poor implementation of agreed trade reforms could be improved by adopting proper monitoring mechanisms, perhaps similar to the European Union's "Single Market Scoreboard". In addition to providing vital information, the scorecard is useful as a disciplinary measure- to shame governments with a record of poor implementation into action and to empower governments with good records of implementation and hence challenge those members who are not meeting commitments.

Second, more effort is required towards macroeconomic policy co-ordination. These countries have been pursuing very similar policies under the auspices of the IMF and the World Bank in terms of economic restructuring. However, from the results obtained, it can be inferred that a more proactive economic policy co-ordination will be beneficial to the region and should be encouraged. A resolute effort must be made to achieve greater institutional and economic policy convergence. This assumes that countries establish ambitious, but feasible timetables for instituting reforms and establishing regional institutions, while realistically evaluating the resources required. These efforts will reduce income divergence and as a result translate into deeper economic integration efforts by members. The evidence of income divergence across and within the three trade blocs' countries is an interesting finding as it creates new challenges including political tension in the process of pursuing deeper integration in the region.

The finding that political instability significantly and negatively affects economic growth has important implications for economic development of African countries. If political instability has a negative impact on economic growth, then it should be considered as an integral part of economic development policy formulation and implementation. The implication of these results is that economic policy makers should consider the impact of policy changes on political stability when formulating and implementing economic policy. Better still, economic policy could be combined with polices designed to increase political stability.

In sum, this study suggests that in order to be successful, any growth oriented adjustment strategy aimed at getting Africa out of the 'low level equilibrium trap' need to tackle a number of issues. These issues include, reducing impediments to deeper economic integration, boosting savings and reducing poverty, making efforts to restore peace and ensuring social and political stability, improving institutions and their performance, implementing policies to achieve policy coordination, harmonization and ensuring macroeconomic convergence, building and sustaining genuine democracy, maintaining the essential political will for integration, developing mechanisms to deal with challenges of globalization and new membership, dealing with declining import revenues, dealing with supply side constraints such as weak infrastructures and having a built-in automaticity in the schedule for liberalization so that tariff and non-tariff barriers are lowered automatically, among many other issues.

\section{REFERENCE:}

Adams, R., Dee, P., Gali, J. and McGuire, G. (2003): "The Trade and Investment effects of Preferential Trade 
Arrangements- Old and New Evidence" Productivity Commission Staff Working Paper, Canberra, Australia.

Arellano, M. and Bond, S. (1998): "Dynamic Panel Data Estimation Using DPD98 for GAUSS: A Guide for Users", Institute for Fiscal Studies, Working Paper, 88: 15. London

Arellano, M. and Bond, S. (1991): "Some tests of specification for panel data: Monte Carlo evidence and an application to employment equations" Review of Economic Studies, 58: pp. 277-297.

Aryeetey, E. and Oduro, A. (1996): "Regional Integration Efforts in Africa: An Overview" Regionalism and the Global Economy: The Case of Africa, eds. J.J Taunissen: The Hague, FONDAD.

Badinger, H. (2001): "Growth Effects of Economic Integration-The Case of the EU Member States (19502000)", IEF Working Papers, 40.

Barro, R. (1991): "Economic Growth in a Cross-Section of Countries" Quarterly Journal of Economics, 106(2): pp. 407-43.

Barro, J.R. and Sala-i-Martin, X. (1995): Economic Growth, McGraw-Hill, Inc, US.

Bates, R.H. (2005): "Political Insecurity and State Failure in Contemporary Africa", CID Working Paper, 115, Harvard University.

Ben-David, D. (1996): "Trade and Convergence among Countries" Journal of International Economics, 40: pp. 279-98.

Bloom, D. and Sachs, J. (1998): "Geography, demography, and Economic Growth in Africa" Brookings Papers of Economic Activity, 2: pp. 207-73.

Blundell, R. and Bond, S. (1998): "Initial conditions and moment restrictions in dynamic panel data models" Journal of Econometrics, 87(1): pp. 115-143.

Burnside, C. and Dollar, D. (2000): "Aid, Policies and Growth" American Economic Review, 90(4): pp. 847868.

Carmignani, F. (2006): "The Road to Regional Integration in Africa: Macroeconomic Convergence and Performance in COMESA" Journal of African Economies, 15(2).

Collier, P. and O'Connell, A. (2004): "Explaining Africa Economic Growth: Opportunities and Choices", AERC Growth Project Synthesis, Draft Chapter 2, August.

Gunning, W. (2001): "Regional Integration and Strategies for Trade Policy in Sub-Saharan Africa", Economic
Development in Sub-Saharan Africa, eds. Elbadawi and Ndulu: Palgrave.

Iqbal, Z. and Khan, M. (1997): Trade Reforms and Regional Integration in Africa, International Monetary Fund, Washington, DC.

Jenkins C., Leape J. and Thomas, L. (2000): Gaining from Trade in Southern Africa: Complementary Policies to Underpin the SADC Free Trade Area, Macmillan Press Ltd.

Krugman, P. (1991): "The Move towards Free Trade Zones," in Policy Implications of Free Trade and Currency Zones. A Symposium Sponsored by the Federal Reserve Bank of Kansas City. Jackson Hole, Wyoming, August 1991.

Landau, D. (1995): "The Contribution of the European Common Market to the Growth of Its Member Countries: An Empirical Test" Weltwirtschaftliches Archiv 13(4): pp. 7774-7782.

Levine, R. and Renelt, D. (1992): "A Sensitivity Analysis of Cross-Country Growth Regressions" The American Economic Review, 82(4).

Levine, R. and Renelt D. (1991): "Cross Country Studies of Growth and Policy: Some Methodological, Conceptual, and Statistical Problems" World Bank Paper Series, 608.

Levine, R. and Zervos, S. (1993): "Looking at facts: What we know about Policy and Growth from Cross Country Analysis", World Bank Policy Research Papers, WPS 1115.

Lyakurwa, W. (1996): "Trade and Investment Integration in Sub-Saharan Africa", Regionalism and the Global Economy: The Case of Africa, eds. J.J Taunissen: The Hague, FONDAD.

Ndung'u, S.N. and Goldsten, A. (2001): "Regional Integration Experience in the Eastern African region", OECD Technical Paper, 171.

Oyejide, A. and Elbadawi, I. (1997): Regional Integration and Trade Liberalization in Sub-Saharan Africa: Frame work, Issues and Methodological Perspectives, London, Macmillan, 1.

Puga, D. and Venables, A. (1998): "Trading Arrangements and Industrial Development" World Bank Economic Review, 12, pp. 251-270.

Sharer, R. (1998): "Trade Liberalization in IMF-Supported Programs", in the IMF World Economic and Financial Surveys, IMF, Washington D.C. 
Solow, R. (1956): "A Contribution to the Theory of Economic Growth" Quarterly Journal of Economics, 70 (1): pp. 65-74.

Spilimbergo, A., Londono, J. and Szekely, M. (1999): "Income Distribution, Factor Endowments, and Trade Openness", Inter-American Development Bank (IADB) Working Paper, 356, Washington, DC.

Torstensson, R. (1999): "Growth, Knowledge Transfer and European Integration" Applied Economics, 31, pp. 97106.

United Nations Economic Commission for Africa (2004): Assessing Regional Integration in Africa, UNECA Policy Research Report.

Vamvakidis, A. (1999): "Regional Integration Arrangements or Broad Liberalization: Which Path Leads to Faster Growth?" IMF Staff Papers, 46(1): pp. 42-68.
Vanhoudt, P. (1999): "Did the European Unification Induce Economic Growth? In Search of Scale Effects and Persistent Changes" Weltwirtschaftliches Archiv, 135(2), pp. 193-219.

Venables, A. (2003): "Winners and Losers from Regional Integration Agreements" Economic Journal, 113, pp. 747-761.

Walz, U. (1998): "Does the Enlargement of a Common Market Stimulate Growth and Convergence?" Journal of International Economics, 45, pp. 297-321.

Walz, U. (1997): "Dynamic Effects of Economic Integration: A Survey" Open Economies Review, 8(3), pp. 309326.

World Bank (2006): World Development Indicators 2006, Data on CD-ROM, Washington, DC: World Bank.

World Trade Organization (various years): World Trade Reports, Geneva, WTO. 